\title{
AUSTRONESIAN LOANWORDS IN YOLNGU-MATHA OF NORTHEAST ARNHEM LAND*
}

\author{
Alan Walker and R. David Zorc
}

For well over a century scholars have been aware that some Aboriginal languages contained loanwords from languages spoken in the islands to the north of Australia.1 Although early authors spoke of 'Malay' influence ${ }^{2}$ or, more accurately, of 'Makassan' contacts, ${ }^{9}$ they conceded that the influence need not necessarily have been from a single language group. Speakers of various Austronesian languages had made trips, primarily concerned with the trepang industry, to the north coast of Australia from before $1800^{4}$ until 1906.5

Linguists currently use the cover term Austronesian, rather than Malayo-Polynesian, the term favoured earlier (but now applied to a subgroup of Austronesian), to classify the family of languages spoken from Formosa in the north to New Zealand (Maori) in the south, from Madagascar (Malagasy) in the west to Easter Island or Hawaii in the east. We are dealing here with members of the western branch of this family, particularly Makassarese and Buginese, who came into contact with speakers of Aboriginal languages on the Arnhem Land coast. Other possible contacts include speakers of Malay and Javanese, central and southern Philippine Bisayan slaves (used on trepang expeditions), southern Philippine Lanaw pirates (who apparently operated off the coast of northern Australia), and Bajau entrepreneurs.

Numerous articles have been written on the topic of Macassan influence on Aboriginal languages, ${ }^{6}$ but no serious effort has been made to identify the precise donor languages on scientific linguistic grounds. ${ }^{7}$ As Macknight has observed:

Enough is now known about the Macassans to set some limit to their usefulness as a general ragbag source of the unusual. This is not to say that there have been no other external cultural influences in northern Australia, but discussion of such other influences should also specify the presumed source of the influence

\footnotetext{
- We would like to thank Joyce Ross for access to a preliminary draft of a Gumatj-English dictionary, and those Yolngu-Matha speakers who have been most helpfúl in identifying Makassan loan words: James Galariwuy, Tom Bakamana, Charles Nawungurr, and Jimrny Dhopan Yumupinu (Gumàtj), John Gupaniry Wunugmurra (DhaLwamu), Florence Nalawurr(Djapu), Jack Badaltja Dhurrkay (Wangurri), Betty Marrnanyin Gurruw iwi (Galpu), Gordon Lanyipi Marrkula and Thomas Maywunydjiwuy Gaykamanu (Gupapuynu), and Dorothy Buyuminy Ganambarr (Djambarrpuy ju). We are grateful to J. Noorduyn for extensive help in identifying Buginese cognates and for the isolation of a Salay ar form (\#73) and other data. Other scholars who have offered much advice and assistance are: Geoffrey Benjamin, Paul Black, Tom Dutton, Luise Hercus, C.C Macknight, Virginia Matheson, Frances Morphy, and James Urry. We assume full responsibility for errors of presentation, interpretation, or fact.
}

1 See Earl 1842:140, Jennison 1927, Lowe 1976, Macknight 1976:89, and Urry and Walsh 1981.

2 For example, Jennison 1927:178, Warner 1932.

3 For example, Earl 1842, Worsley 1955, Macknight 1972, 1976, Tumer 1974.

4 Macknight 1972:284 states: 'The Makassan industry was certainly in operation by about 1760, and is most unlikely to have been so long before 1700 . It thus endured for approximately two centuries'. See also Worsley (1955:2) who reports that 'The written historical records of Macassarese and Buginese enterprise go back to 1768 .

5 See Macknight 1972:284, 1976: Chapter 8. In 1906 the South Australian government, then responsible for the Northern Territory, ceased issuing licences to foreign trepang fishermen; after a brief exploratory test of these regulations (November 1906 to February 1907) the Macassan industry terminated.

6 See the bibliography in Macknight 1976:166-169 or his earlier work 1972:318-321.

7 Wirjosuparto 1969 was a first step in this direction, but suffers from several deficiencies: (1) the Aboriginal languages are not identified and represent data from genetically-diverse varieties (e.g., Anindilyakwa, Burarra, Yolngu-Matha, and Nunggubuyu); (2) most of the data is neither phonemic nor phonetic (3) the quality of some of the evidence suggests little more than guesswork or chance aggreements (e.g., relating the names of the two moieties, yirica (yirritja) and duwa (dhuwa) to Makassarese juragan 'shipmaster' and tua 'old'). See also Macknight 1972. 


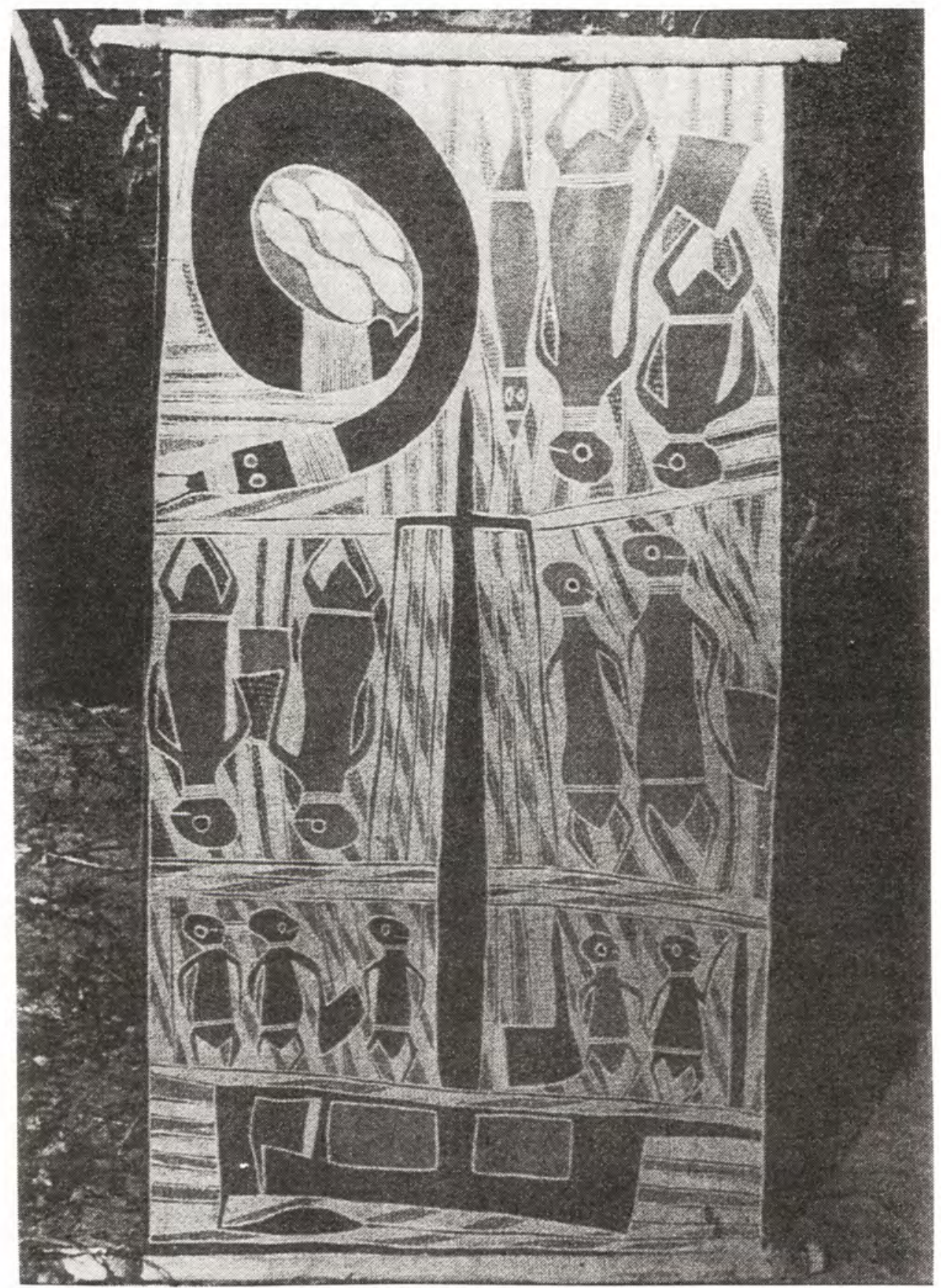

Bark painting by Mithinari (193?-1976), Galpu clan, Yirrkala, northeast Arnhem Land. It represents Yolngu and Macassans in Arnhem Bay. The Macassans, arriving in a prau, bring with them steel axes to replace Yolngu stone axes. The painting, done in 1974, is in the National Ethnographic Collection, Canberra.

Photograph and description courtesy of Howard Morphy 
and when and how it might have arrived, or if such precision is not possible, clearly say so ... . Further publication of linguistic work in northern Australia should make more definitive lists possible. However it is worth stressing the complexity of the linguistic issues involved and the difficulty of obtaining anything approaching a complete conspectus of Aboriginal knowledge of relevant vocabulary items. $^{8}$

Macknight points out that Makassarese is obviously 'the most important source of influence', although Buginese, Malay and Javanese are worthy of investigation since some crew members appear to have been able to speak these languages. ${ }^{10}$

This paper will be concerned with Yolngu-Matha, the speakers of which live mainly in northeastern Arnhem Land at Yirrkala, Milingimbi (Yurrwi), Elcho Island (Galiwin'ku), Lake Evella (Gapuwiyak) and Ramingining as well as on outstations of these settlements, and deep into Arnhem Land as far south as Roper River. It is our purpose to offer a preliminary conspectus of lexical items we have noted in our work in dialects of Yolngu-Matha ${ }^{11}$ that impressed us as Austronesian in nature. ${ }^{12}$ Since between us we have a good knowledge of several Austronesian languages ${ }^{13}$ and of historical Austronesian reconstruction, we feel confident to initiate this endeavour, in the hopes of gaining the assistance of other scholars to further this work.

Neither of us has had direct access to Makassarese or Buginese informants, and we have had to rely on Dutch dictionaries ${ }^{14}$, so we make no claim to comprehensiveness. To date, we have identified approximately two hundred forms that can reasonably be associated with one or another Austronesian language. We have avoided forms that are 'remembered' by very old Yolngu people as being Makassarese ${ }^{15}$, or those that are not of general knowledge and use, such as specialised boating vocabulary. ${ }^{16}$ Another area we have excluded are names used exclusively for persons or places which have no known or traceable meaning. Our procedure is to set out suspected borrowings into four groups:

(1) most probably Makassarese, based on soundshifts or innovations limited to that language ${ }^{17}$

(2) possibly Makassarese, but possibly other Austronesian languages, since identical forms are found in many Austronesian speech varieties;

8 Macknight 1972-291,295. Note Macknight's definition: 'The term "Macassan" does not refer to any racial, linguistic or cultural group as such. It refers simply to any person who came on the annual fleet of praus to the Northern Territory. Even an Aborigine, when travelling with the trepangers beyond his normal ambit, can be included within the definition' (1976:1-2).

9 Macknight $1972: 294$.

10 Macknight 1972:294-295.

11 The term 'dialect' is used here without prejudice to the possibility that some speech varieties may not form a chain of mutual intelligibility. Most YM speakers are at least bilingual(father's dialect and mother's dialect), and many are multilingual since they come from communities where up to a dozen different varieties are spoken. See footnote 19.

12 Initially our judgments were 'impressionistic', i.e. words 'sounded' like Malay or Austronesian words we knew, but these were later confirmed by research into Makassarese, Malay and other Austronesian languages, and led to the establishment of Groups 1-3 in this paper; Group 4 remains 'impressionistic'.

13 These include: Bahasa (Malay or Indonesian), Filipino (Tagalog), Bisayan (and several other southern Philippine languages), Sawu, Sumba, Manggarai, Ndao, Timor, Belu, and Helong/Kupang[the latter seven spoken in western Timor and adjacent islands (Flores, Sumba, and Ndao)].

14 Matthes 1859 (1885); Cense 1979.

15 See Macknight 1972:297; 1976:89 on 'pepper-potting'.

16 See Macknight 1972:297-300, 1976:89.

17 In an unpublished paper, Nothofer 1970 discusses some of these; we have also worked the standard reflex es out for ourselves. Certain sound shifts earmark some borrowings as exclusively Makassarese, particularly the shape of the words that ended in ${ }^{*}-D_{,}^{*}-R,{ }^{*}-r, *-s$, and $*-1$, where a support vowel and glottal stop have been added $(15,20,25,33,43,65,82,89,97,99)$ whereas Buginese has replaced the final consonant with - ${ }^{2}$ (see $15,20,21,33,97)$. Another outstanding feature (shared with Buginese) is the change of all final nasals to- $-1(10$, $36,47,53,56,58,84,90)$. The loss of final stops $(11,30,51,59,69,79,85,93)$ is common to several languages besides Makassarese and Buginese, but is not found in Malay, Indonesian, Javanese, and Southern Philippine languages. 
(3) not Makassarese, but clearly Austronesian, based on word shapes, sound- or meaningshifts not found in Makassarese, but found in other Austronesian languages; or

(4) possibly Austronesian, but precise donor forms have not yet been identified, established or proven.

Each of these groups will be discussed in greater detail below. ${ }^{18}$

A brief discussion of the phonology of Yolngu-Matha and Makassarese is necessary in order to see how borrowings from the latter are mapped into the former. The phonology of Yolngu-Matha (which includes speech varieties such as Gupapuynu, Gumatj, Djambarrpuynu, Rirratjinu, Gälpu, DhaLwanu, and Ritharrnu ${ }^{19}$ is given in Table 1.20 The phonemic system of Makassarese is given in Table 2. The phonetic interpretation is based on two published phonemic statements, ${ }^{21}$ comparison with other Austronesian languages, and the shape of loanwords in Yolngu-Matha. Thus, Mkr $\mathrm{t}$ is dental $[\mathrm{Mkr} \mathrm{t}>\mathrm{YM}$ t or d] $(12-13,25,26,31-34,47,53,98)$, while d is alveolar [Mkr d > YM t or d] $(07,28,29,30,39,46,81,85)$. Since YM has no spirant, $\mathrm{Mkr} s>\mathrm{YM}$ j in initial position (53,60, 61, 63-70; less frequently d- as in 35-37, 119), but YM $\mathrm{c}$ in intervocalic position $(48,60,63,86,89,100,111$; less frequently $\mathrm{t}$ as in 82,83$) .{ }^{22} \mathrm{Mkr} r>\mathrm{YM} \mathrm{r}$ (there are no provable instances of $R ;{ }^{23} 11,13,15,19,20, \overline{21}, 26,31,33,39,42,44,45,46,55,57$, $58,65-70,73,74,76,82-84,90-95,97,99)$. Mkr $1>$ YM $1(01-03,05,06,09,12,19,23,24,29$, $35-37,40-43,50,51,53,62,63,68,71-81$; less frequently $L$ as in $04,25,76,78.163)$. M kr is preserved in two known clusters $(09,62)$ and sporadically in word-final position $(01,11$, $20,30,43,65,69,70,97)$, but analogically introduced on forms where it never occurred $(08,14,53,98$; note its loss on $05,06,12,15,21,22,23,25,26,29,31,33-35,39,41,42,45$, $48,49,51,52,59,60,63,66,68,71-74,76,77,79,81-83,85,89,92,93,99)$. A stressed vowel in the first syllable of a $\mathrm{Mkr}$ word not followed by a geminate consonant is usually interpreted as a long vowel in $\mathrm{YM}(10,11,14,15,17,18,20,23,26-30,34,35,48,49,54,57$,

18 From now on the following abbreviations will be used when specific languages are discussed:

AN Austronesian

Baj Bajau

Bis Bisayan (Cebuano)

Bug Buginese

Ind Indonesian

Jav Javanese

Mal Malay

Mar Maranao (SPh)

Min Minangkabau Malay

\author{
Mkr Makassarese \\ PAN Proto Austronesian (c. 8000 B.P.) \\ PHN Proto Westem Austronesian (c. 3000 B.P.) \\ PIN Proto Indonesian (c. 2500 B.P.) \\ PMP Proto Malayo-Polynesian (c. 5000 B.P.) \\ Port Portuguese \\ Skt Sanskrit \\ SPh Southern Philippine \\ YM Yolngu-Matha
}

19 Zorc 1978 and 1979 has refined a subgrouping of Yolngu-Matha (originally made by Schebeck n.d.): Southern Yolngu includes a group of closely related dialects (Gumatj, Gupapuynu, Djambarrpuygu, Liyagawumirr), Djapu, and DhaLwagu; while MaDarrpa, Wagilak, and Ritharrnu are closely related to each other and more distantly to southern Yolngu; Northern Yolngu includes another group of dialects (Gälpu, Rirratjigu, Wangurri, and Warramiri) and the more distant Golpa. The rift between Northern and Southern Yolngu vocabulary and grammar is wide and should be great enough to bar mutual intelligibility, but so many speakers are bilingual that it is difficult to substantiate this by mutual intelligibility testing alone. Unless otherwise noted, the words cited in this paper are known to and used by speakers of all these varieties of Yolngu-Matha.

20 We have 'normalised' the orthography of both $\mathrm{YM}$ and $\mathrm{Mkr}$ in order to highlight the mapping of the two systems. In $\mathrm{YM}$ orthography dentals are written with an $\mathrm{h}$ digraph (dh, $\mathrm{th}, \mathrm{nh}$ ), palatal stops with a j digraph $(\mathrm{dj}, \mathrm{tj})$, but the palatal nasal with $\mathrm{y}(\mathrm{ny})$, retroflexes are underlined $(\mathrm{d}, \mathrm{t}, \mathrm{n}, \underline{\mathrm{l}}$ ), while the rhotics are distinguished by single $r$ (retroflex) and double $r r$ (trill); long vowels are written as a [a:], e[i:], and o[u:]. The symbol -2 is used in Indonesian and Malay to indicate the full reduplication of a stem, e.g. bálla ${ }^{3}-2=$

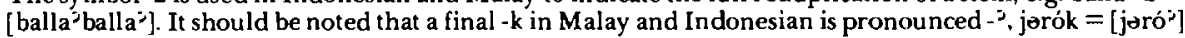
(177).

21 Ngewa 1972 and Cense 1979.

22 Earl 1842:140 noted that Aborigines could not pronounce the [s] sound. This is perhaps the greatest single change from the Mkr source forms, with shifts in voiced/lax vs voiceless/tense distinctions being second (see below). All in all, however, Yolngu-Matha was perhaps the best equipped Aboriginal language group to 'copy' Makassarese phonetics and phonotactics.

23 Therefore we have retained only two suspect forms with $\mathrm{R}(216,237)$, while a large number of others have been excluded on these grounds: giRiRirk 'calico, fabric', guRipa 'fish-hook', guwacuRu 'canoe', maRtana, maRtanay 'boat, ship', Ra:w' (Ritharryu) 'body-hair, fur' (cf: PHN *Da:hun 'leaf), Rupa 'tin, cup'. Retroflex $R$ does not appear to have any viable $A N$ source. 
TABLE 1. PHONOLOGY OF YOLNGU-MATHA

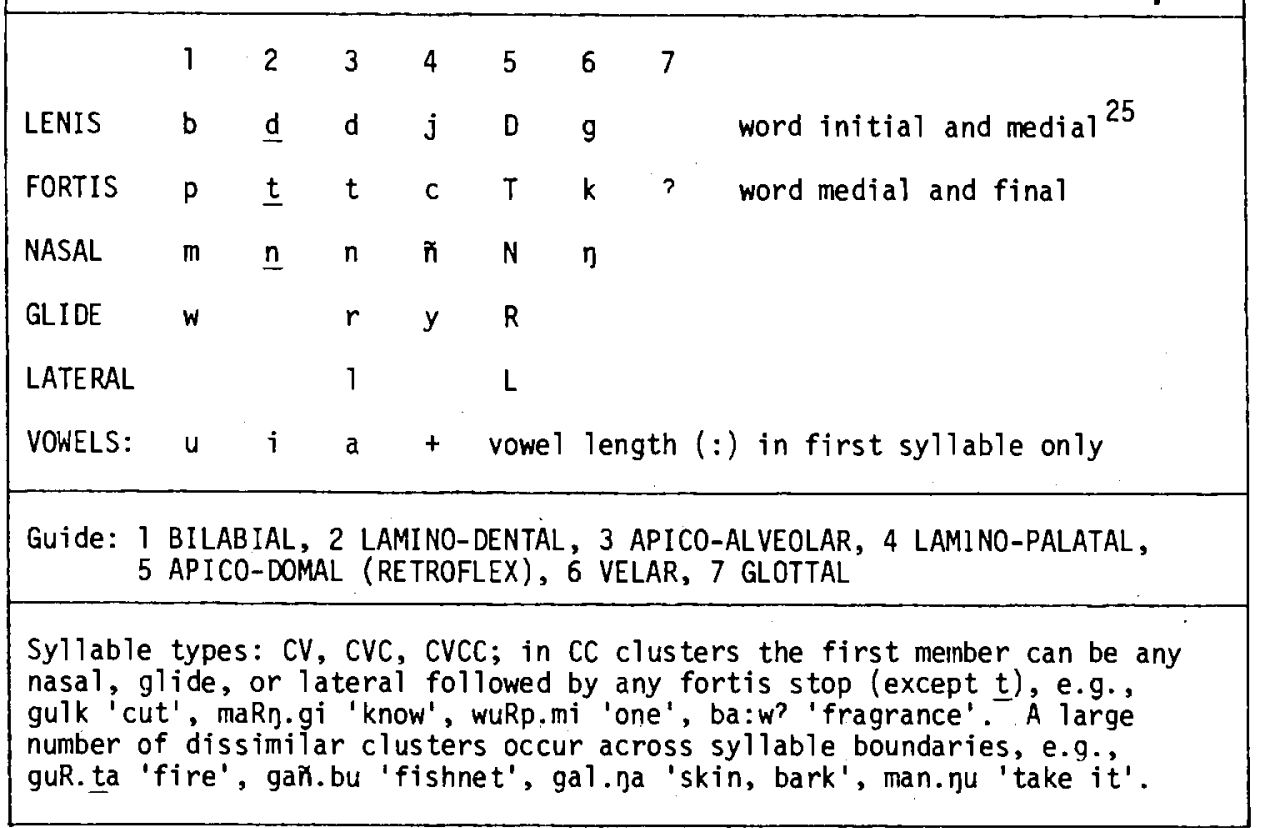

TABLE 2. PHONOLOGY OF MAKASSARESE.

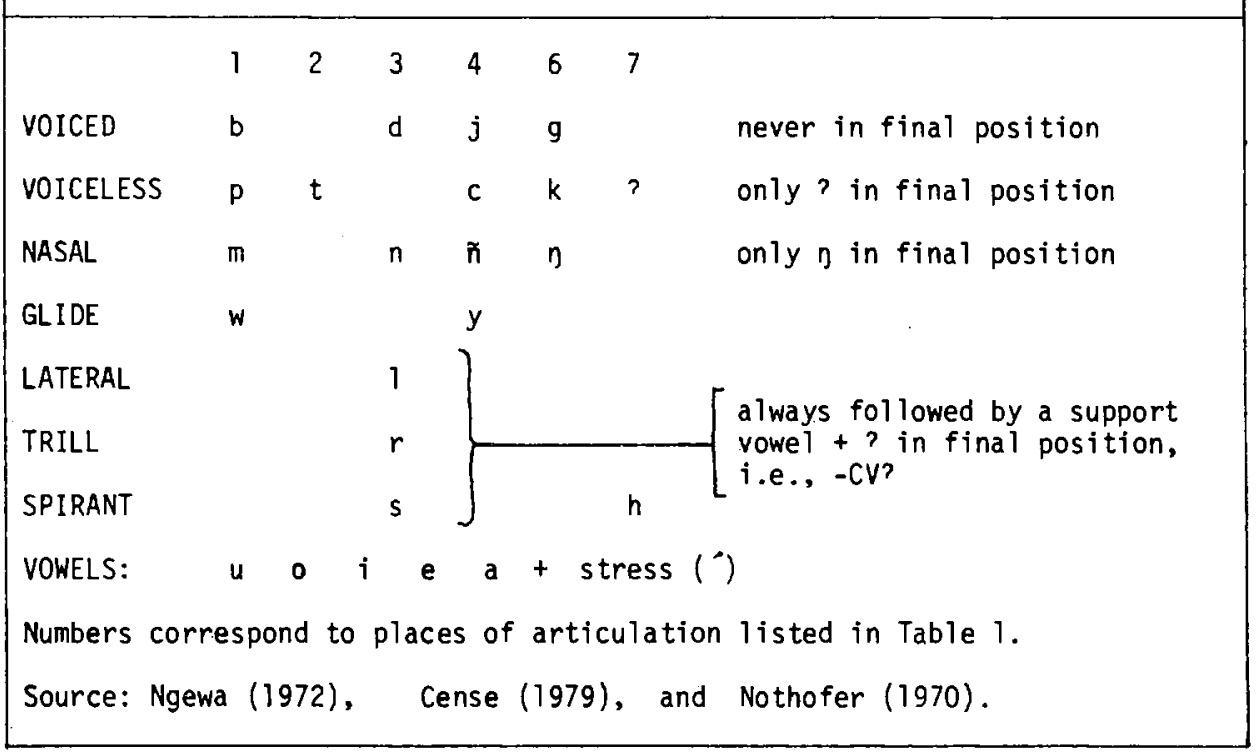

25. An alternate hypothesis could eliminate one of the series of stops by positing geminate stops contrasting with non-geminate stops in intervocalic position, otherwise a stop is lenis word-initially and fortis word-finally, e.g., [bá:pa'] = /pá:ppa/'father', [bábaji] = /pápaci/ personal name. 
$59,62,65-70,78,79,83-85,89,90,92,94,95)$, otherwise when stress falls on a vowel before geminate consonants $(01,07,08,12,22,43,47$, etc.) or other than in the first syllable $(03$, $04,13,16,19,24,36,39,40$, etc.), such vowels are interpreted as short in YM. ${ }^{24}$ Generally speaking, the mapping is reasonably straightforward following the allowed (canonical) shape of inherited words, so that initial stops in $\mathrm{Mkr}$ (whether voiced or voiceless) are interpreted as lax (e.g., Mkr b-, p->YM b- in 01, 03, 04, 08 vis 05-07, 09, 10, etc.; Mkr g-, $\mathrm{k}->\mathrm{YM}$ g- in 4l, 129, 131-134 vs 39, 40, 42-51, etc., Mkr j-, c-> YM j- in 54, 56, 58, 59 vs $55,57,62$, etc.). However, it is important to note that the number of syllables and the basic vowel quality (high vs low, front vs back) is copied in YM quite faithfully, so that YM bingal 'axe' could not reflect Mkr pánkulu' 'axe' or bínkun 'adze' (see 188). Only a few exceptions have been noted $(35,36,37,86,87,98,118$, 129, 139, 199) where YolnguMatha does not reflect the donor language sound-for-sound and syllable-for-syllable, but the departure is never drastic (as would be the case in Anindilyakwa, for example), and can be explained by standard or natural changes (assimilation, reduction, epenthesis, or syncope).

The productive Makassarese suffix -an, used inflectionally in making passive verbs and derivationally in making nouns denoting place or instrument, e.g., bandéra 'flag', banderán 'flagpole, place where flag waves', has apparently led to several analogies in Yolngu-Matha whereby $-\eta$ has been dropped from Makassarese forms as if it were an unnecessary suffix $(06,07,13,23,24,44,55,66,81,91,100,106,121,134,137,142,150)$, and a few cases where it has been added as if it were a noun-formative $(98,111,118,119$, $135,141,145,155)$.

Since Yolngu-Matha does not allow vowels to occur initially in words, w- is added before $\mathrm{u}$ - $(97,98), \mathrm{y}$-before $\mathrm{i}$ - or $\mathrm{e}-(99)$, and either $\mathrm{n}$ - or $\mathrm{w}$ - before a- (contrast 89 , 236 vs 96, 158; note also wacpil < English hospital).

Since this study is aimed primarily at the identification of Austronesian source languages for Yolngu-Matha words (based on resemblances in sound and meaning), it would seem useful to present an index oriented to various semantic and cultural domains in order to highlight the many areas of impact on Yolngu material culture and language. Dubious forms (from Group 4) are omitted. ${ }^{26}$

\section{INDEX}

BOATING: anchor $(04)$, boat $(43,86,161)$, sail $(35,45,175)$, canoe $(80)$, inside of boat (49), rudder (134); telescope (123).

BUILDING: house (01), shelter (02), plank (10), steps/ladder (34), plane (47), timber (41), to build (54, 189), saw (129).

CLOTHING AND ADORNMENT: thread (08), needle (58), to sew (59), shirt (101-2), trousers (139), shoes $(119,145)$, cloth $(57,79,106)$, hat (148); necklace (132), earrings (146), perfume (113); naked (68).

COMMERCE AND TRADE: to pay (15), to count (26), money $(30,156)$, cheap (74), costly (93), rich (24), poor (126), size (52), equal (91), adequate (92), to buy (120), few $(71,136)$, to change/barter (143), separate (170).

DISEASE: medicine (09), ringworm (115), spots (116), diarrhoea (83).

DRINK: alcoholic-beverages (89), drunk (32, 78, 87); bottle (25).

FISHING: fish-hook (17), to dive (36-7), sinker (151, 218); goggles (186).

FLORA AND FAUNA: pig (14), sheep/goat (18), buffalo (28), horse (56), dog (166), horn (118), prawn (38), mudcrab (61), jellyfish (90), trepang (121), coral (128), pearl $(50,153)$, turtle-shell $(60)$; string-bark (51), bamboo (112), tamarind (141); jungle (95). 


\section{AUSTRONESIAN LOANWORDS}

FOOD: corn (19), rice (20), coconut (39, 40, 46), salt (62), banana (98), syrup (133), bread (157), potatoes/vegetables (162); to boil (94).

LITERATURE: paper (27, 69), book (69), to write (97).

METAL: tincan (100), tin/iron (140), wire (146), lead (151, 218), chain (155).

MUSICAL INSTRUMENTS: drum (31), mouth-organ (147).

PEOPLE AND PERSONAL CHARACTERISTICS: greedy (03), robber (05), Makassan $(13,21,82)$, white-woman $(16,154)$, white-person, European $(103,247)$, boss (114).

RELIGION: lord (44), light, radiance (65), prayer (142); grave-post (246).

SEX: to masturbate (176), smooth $(72,77$ - used in a number of idioms with direct sexual reference). ${ }^{27}$

TOOLS AND WEAPONS: revolver (63), rifle (64), gun (84), fighting-stick (104), knife $(81,107,127,150,160)$, axe (165), digging-stick (180), shovel-nnse spear (172).

WIND-DIRECTIONS: west (wind) (11), northeast (wind) (33), south (wind) $(53,174)$.

MISCELLANEOUS ITEMS: pillow (06), gambling (29), mirror (55), spoon (66-7), bucket (99), flag (105), bag/sack (108, 171), bowl (111), prison (122), key (135), soap (137), lamp (149), paint/tar (152), eyeglasses (159).

Of particular interest is the presence of Austronesian words in the basic vocabulary:28 big (12), day/sun (96), do/work (54), feather (163), forehead (22), fragrant (110), good/nice $(72,77)$, heel (167), high/tall (124), moon (23), rear/behind (168), short (169), smooth (76), sour (177-8), stone (109), tall/long (73), tooth (131), tree/wood (130), wind/air (158), year (125), yes (179, 249), and a tag-question particle (88). An unwary lexicostatistician might find that Yolngu-Matha has enough 'cognates' (5-10\% depending on how one scored) to be grouped distantly with the Austronesian family - a tenet ludicrous in the context of Australia, but not so (for at least some scholars) if these languages were spoken in New Guinea instead.

Of considerable importance is the impact on Yolngu-Matha grammar, whereby a new verb type has been formed. Whereas Yolngu-Matha verbs fall into several classes and have at least four inflectional categories, ${ }^{29}$ a new class of verbs has emerged which have only one basic inflection $(26,54,97,138,143) .{ }^{30}$ The use of $\mathrm{Mkr}$ stems in YM compounds $(59,83)$ is similarly noteworthy.

Thus, there is a substantial Austronesian imprint upon Yolngu-Matha. In speaking about Malay loanwords in Tagalog, Wolff has noted:

Their very number as well as their character indicates that there must have been a considerable population in the Tagalog speech community which could speak Malay. Some of these Malay borrowings are words of an ordinary, everyday character: forms referring to personal characteristics, ... words for parts of the

27 The practice of a kind of forced homosexuality by or with Makassans has not been discussed to our knowledge in the literature, but should not be prudishly dismissed. The Yolngu guarded their vomen, not only from the Makassans but also from the young Yolngu who had not achieved the age, prestige, or ceremonial status to claim a promised wife (hence the traditional marriage of older men with younger girls). There are several affectionate or pejorative curses in YM that strongly suggest homosexual activity (gurka laycu 'smooth penis', mu:ku laycu 'smooth anus', mu:ku bu:lk-miri 'anus with semen') which is no longer practised due to the now acceptable marriage of young with young. The presence of an AN (SPh) word for 'masturbate' and of the Mkr for 'smooth' in these idioms does not necessarily imply the introduction of such activities by Makassans (including Bisayan slaves on the boats), but reveals the likelihood of sharing such activities with $\mathrm{Mkr}$ or other AN speakers.

28 Not all of these would be found in either the Swadesh 100 or 200 word list, but do represent very common words used daily by YM speakers. Enough of these would yield the 'false' percentages cited below, regardless of the list chosen and the items deselected from this list.

29 Base form, definite future, indefinite past, and definite/remote past, e.g., Gumatj waya, wayi, wayana. wanana 'speak', maltun, malturu, malıuruna, maltuna 'follow', buma, bunu, bumaRa, buga 'hit, kill', etc.

30 Macknight 1976:89 cites 26,54,97, 138, but not 143; however, he includes bilina 'to finish' (<Mkr, Mal bílan 'to reckon, count'), which is an unlikely ety mology [due to poor match of sound (YM *bi:lan would be expected) and meaning]; furthermore, dialects which drop the final vowel from function words (Djambarrpuypu, Liy agaw umirr, etc) have the for $\mathrm{m}$ bilin, which suggests it is a genuine YM word, i.e., they do not show signs of vowel-dropping from non-inherited words. 
body, and others of the type that refer to things for which there must have been good native terms. Such basic vocabulary can only have come in if members of the Tagalog speech community could speak Malay. ${ }^{31}$

Such a situation appears to have obtained where (a form of) Makassarese was used as a pidgin or patois for speaking to foreigners (be they trepangers, Europeans, or speakers of other Aboriginal languages). ${ }^{32}$ Furthermore, even where perfectly adequate YolnguMatha terms existed, adoption of Makassarese forms was surely favoured by the need for synonyms to replace words tabooed because of death: thus 05 is synonymous with YM manangan 'thief', 12 with YM yindi 'big', 23 with YM yaLindi 'moon', 32 with YM jawuLpa 'old-person', 60 with YM naRaka 'bone; shell', 51 with YM Na:ku 'stringybark', 61 with YM nu:ka? 'mudcrab', 65 with YM baDayala 'light', 68 with YM waranul 'naked', 73 with YM wi:yin ' 'long', 72 and 77 with YM manmak 'good, nice', etc. ${ }^{33}$ Note also the many introduced synonyms for coconut, cloth, and knife (above). Thus, although the contacts ceased some seventy-five years ago, they must have been intensive and long enough to have left such an impact on the language and (perhaps less obviously) the culture of the Yolngu bloc. ${ }^{34}$

Clearly the main source language for Yolngu-Matha words is Makassarese. Most of the 99 forms in Group 1 show characteristics of shape or soundshift that earmark them as Mkr. In several instances, Buginese has identical forms, some of which $(25,29$, $31,33,43,45,89,99)$ are anomalous and which are themselves suspect of being under Makassarese influence. Since no clear instances of Buginese etymologies have thus far presented themselves, we have not assigned any weight to such co-occurrences, and take the $\mathrm{Mkr}$ provenance to be the most probable.

The 59 words in Group 2 also have a high probability of being from Makassarese, although (near) identical forms in other Austronesian languages prevent any definitive statements in this regard. A particular problem that arose was the loss or addition of final $-\eta$ on a number of forms (discussed above). In the absence of any evidence that there is an Austronesian language with precisely such forms that have undergone the same changes, it is most reasonable to assume that the Yolngu coined these forms on their own from $\mathrm{Mkr}$ material (based on analogies or abstractions from their understanding of $\mathrm{Mkr}$ grammar).

The 21 words in Group 3 should be of particular interest, because they are least likely to be $\mathrm{Mkr}$ in origin, although our science and our sources do not allow us to state from which language they derive. The citation of Malay or Southern Philippine forms should not be construed as an indication that they come from these languages, since the full linguistic and historical picture of the islands to the north of Australia has yet to be ascertained. For example, it is known that the Bisayans [bisayá?] of the central and southern Philippine areas have been taken as slaves by various Philippine and Indonesian groups (the word means 'slave' in Maranao and Tausug). It is known that the Tausug of Jolo (Sulu) traded slaves with the Buginese (and thence to the Makassarese). ${ }^{35}$ If Bisayan slaves were on the Makassan trepang boats, then the presence of forms like 159, 163, 165,

Macknight 1976:89 notes: 'Probably the most com themselves. They describe many of these loan-words as 'Old Testament' - that is, slightly archaic synonyms for other terms in common use.' This is true of many words omitted from this study, but not for the bulk of the words presented here. In a literacy class at the School of Australian Linguistics consisting of 21 YM speakers, students were asked to spell forms 0.1-178 (and several items from Group 4). Approximately 120 of the words were known to all of the students, while each of the other 80 words were known by at least six speakers as viable forms or synonyms. Ages ranged from 18-28 and various dialects of both Southern and Northern Yolngu were represented (see footnotes 19 and 39).

34 The use of $\mathrm{Mkr}$ and $\mathrm{AN}$ nouns and names as personal names, synonyms equally affected by the death taboo, innovations in the funeral ceremony, bark and rock paintings, openness to and awareness of other races and cultures, new artifacts and foodstuffs and uses thereof, introduction of new totems (generally) as members of the Yirritja moiety - to cite a few. See.Macknight 1976:88-92 and Urry and Walsh 1981.

35 See Warren 1977 on the extent and impact of the Jolo slave trade; Earl (1859:198) reports on Ilanun 'pirates' shipwrecked on Croker Island. There are thus two sources of SPh loans in YM. (slaves and 'pirates'). 
$166,167,176$, in YM would be less surprising. Several forms $(160,161,162,169,171,172$, $173,174,175,177,178,179)$ may be assumed to be primarily or secondarily introduced through Malay (as a major trade language known to the trepang fishermen).

The words in Group 4 could be taken as Macknight's 'general ragbag source of the unusual' if offered without appropriate caution. ${ }^{36}$ The list is presented to both Australianists and Austronesianists for evaluation and assistance. In most instances, the meanings represent cultural innovations, and Austronesian languages would seem to be the best source; some of these may by Pama-Nyungan ${ }^{37}$ or Yolngu words that have acquired extended or secondary meanings. In still other instances, the words seem to be similar to forms in Austronesian languages, but the matches are not convincing enough. For example, despite a search for possible Bajau loans, based on the lead of Fox ${ }^{38}$ we found only one reasonable candidate (189) $\rightarrow$ and the match is weakened because of its singularity. Finally, we have included forms which Yolngu-Matha speakers insist are from 'Makassan' $(181,182,184,185,194,199,202,204,208,212,216,224,227,237,246$, 247,248 ), on the grounds that a number of such intuitive judgements have been proven in the course of our study..$^{39}$

All in all, we hope to have justified on linguistic and comparative grounds the statements made about the impact of Makassarese (and to a lesser extent, of other Austronesian peoples) upon the Yolngu-Matha speakers of northeastern Arnhem Land. We intend to continue these studies and elicit the help of other scholars in compiling a comprehensive list of loanwords and identifying their provenance.

\section{GROUP 1: MOST PROBABLE MAKASSARESE LOANWORDS}

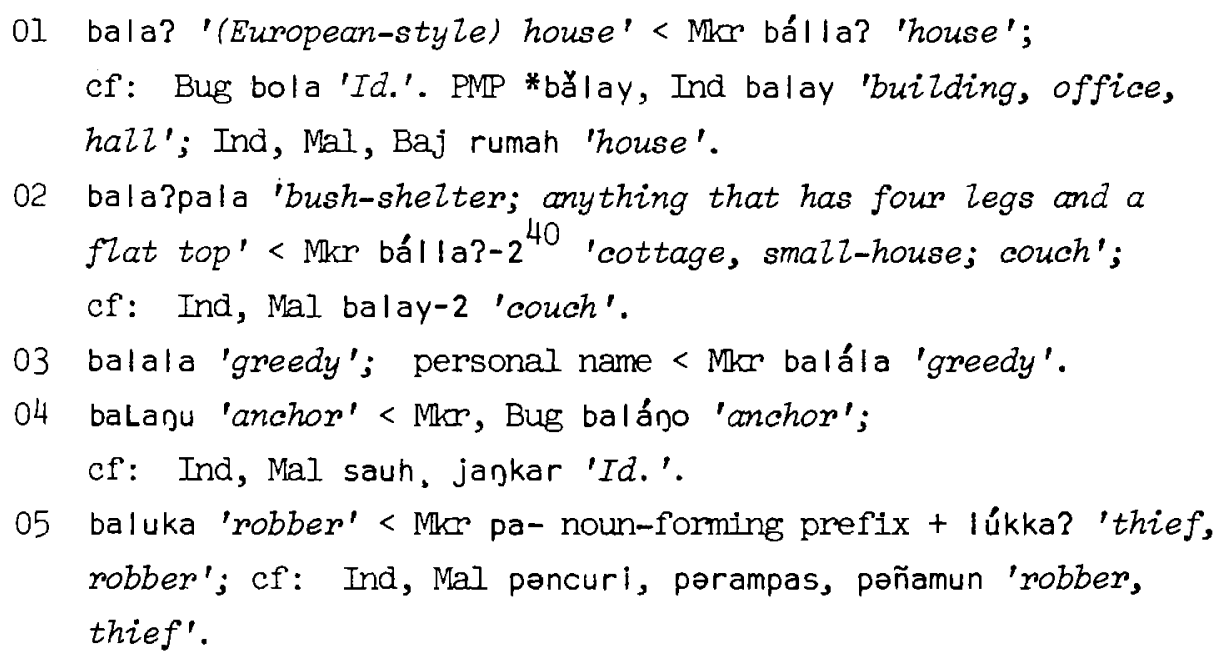

36 Macknight 1972:291.

37 Pama-Nyungan is the name of the proposed parent language of most Australian Aboriginal languages including the Yolngu bloc, but excluding a large number of other Arnhem Land languages, such as Burarra, Nunggubuyu, Anindilyakwa, and other languages that have prefixes or linguistic elements put before (rather than after) the main word. This name comes from the two common words for 'man, Aboriginal' found in the family: pama / nuga.

38 Fox 1977; although our only source of Bajau data to date has been Schneeberger 1937.

39 It is remarkable how many YM speakers (particularly above age 35, but not exclusively so) will state "that word is 'Mangatara"' " or 'bataripay'. In terms of one popular linguistic theory, besides knowing the denotative meaning of a form, they carry a notion [+Makassan] or [+Foreign] along with the connotative meaning. Of course it does not always hold true that the form is Mkr or AN. Once an informant specified gimatata 'baking-powder' as probably Mkr; after a long and futile search for Mkr or AN sources, it finally dawned on us that this was English 'cream of tartar' with a semantic shift. (See also footnotes 33 and 42).

40 The convention of writing - 2 after a word indicates full reduplication in Indonesian and Malay orthography. (See footnote 20 for other conventions.) 
06 baluna 'pilzow' < Mkr pa?lunan 'pilzow' [with -n loss];

cf: Mal bantal, Mar oloja? 'Id.'.

07 bamutuka 'pipe' < Mrr pammudúkan 'bamboo opium pipe' [with -n loss], root word Mkr udu?, Mal udut 'to suck-at, smoke'. 41

08 banan? 'thread(s); wool' < Mkr bánnan 'thread, yarm'; Mal banan, Bug wónnan 'Id.' < PHN *bònan 'thread'.

09 ba:?pali 'medicine; wooden-dish' < Mrr pa?bálle 'medicine', root word bálle 'to medicate'; cf: Mal ubat, SPh bulún 'medicine'.

10 ba:pan 'plank, timber' < Mkr pápan 'board; plate'; cf: Bug pépən, Mal papan 'board, plank'.

11 ba:ra? 'west (wind)' < Mkr bára? 'westwind, rainwind'; cf: Bug báre?, Mal barat 'Id.' < PHN *haba:Rat 'monsoonwind'.

12 batala 'big, large' < Mkr báttala? 'heavy, big, onerous'; cf: Mal bəsar 'big', bərat 'heavy'.

13 bataripa 'Makassarese' < Mrr, Bug patarípan 'trepang-fisherman' [with $-\eta$ loss].

14 ba:wi(?) 'pig' < Mkr, Bug báwi 'pig'; cf: Mal babi 'Id'< PHN *ba:buy 'Id.'.

15 ba:yara 'to pay; pay-back, revenge' < Mrr báyara? 'pay'; cf: Bug wája?, Mal, Jav bayar < PHN *ba:yad 'to pay'.

16 bayinl 'white-woman' < Mkr balne 'woman, wife, female'; cf: Bug wawine, Mal bini 'wife, spouse'. 43

17 bi:kan 'fish-hook' < Mkr pékan 'fish-hook; rod'; cf: Mal kail, pancin 'fish-hook'.

18 bi(:)mbi '(young) sheep' < Mkr, Bug bémbe 'goat'; cf: Mal kambin 'goat', biri-2 'sheep'.

41 Jennison 1927:178 cites Mal pamadutan (sic, correctly pomadatan) 'tobacco or opium pipe', but the phonetic match is with the Mkr form.

42 Informants state that ba:ra' was the wind used by Makassans to sail from Ujung-Pandang to Australia, and dimuru (33) was the wind used to return. This knowledge is borne out to be factual (Macknight 1976:32), and is yet another instance of the knowledge retained about Makassans so long after they have ceased coming to Australia (see also footnote 39).

43 The legends of the bayini are discussed by Berndt and Berndt 1954:33-9; Worsley 1955:2; Mountford 1956:339-8; Macknight 1976:92,97. Since this word is peculiarly Mkr for 'woman' it may refer to a time when some Mkr did visit Arnhem Land with women companions (see Macknight 1976:29), or it may refer to another group such as the Turijene-Bajau (although time and lack of data have not allowed us to check words cited in the above-mentioned studies as 'Bayini'). The linguistic data itself presents an enigma: the word comes from $\mathrm{Mkr}$, yet it refers to 'white-woman' (perhaps alluding to the lighter skin colour of the earlier visitors?). Why the YM speakers did not ascertain (or remember?) the identity of their visitors is puzzling. 
19 birali 'com, maize' < Mkr birálle 'maize';

cf: Bug warálle, Mal jagon 'Id.'.

20 bi:rata? (var: birata?, biraca?) 'rice; wheat; barley' <

Mkr bérasa? 'milled-rice'; cf: Bug bérro?, Mal baras,

Jav wos, Baj buas < PHN *bł̆Ras 'milled-rice'.

21 buki-mangatara (Gum) 'Macassarese' < Mror bugisi? 44 'Buginese' + Mkr mankasara? 'Macassar(ese)'; cf: Bug wugi 'Buginese' + mankasa? 'Macassar(ese)', Mal bugis 'Buginese' + mənkasar 'Macassar(ese)'.

22 buku 'forehead; cliff' < Mkr búkku? 'hump, ridge, Zump; mountainous; roof of a boat'; cf: Bug bukku?, Mal bonkuk 'hump, hunchback(ed)'.

23 bu:la 'moon; dugong-stomach' < Mkr búla? 'round' (or) Mkr bulan 'moon' [with - 1 loss]; cf: Mal bulan, Bug ulan < PMP * bu: I an 'moon' and Mal bulat 'round'.

24 bulay 'rich; jewellery; gold' < Mkr buláen 'gold' [with - 0 loss]; cf: Bug uláwan < PHN *bula:wan 'gold', Mal emas 'gold'.

25 butulu 'bottze' < Mkr, Bug bótolo? 'bottle'; Mal botol < Port botel ha 'Id.'.

26 bu:turu 'to count' < Mkr bótoro? 'to play-dice, gamble'; cf: Bug boto?, Mal bor-judi 'to gamble'.

27 bu:yan 'paper' (archaic word) < Mkr búyan 'paper';

cf: Bug újan 'Id.', Mal kərtas, Mkr karáttasa? 'paper'.

28 di:tun 'buffalo' < Mkr, Bug tédon 'carabao, water-buffalo';

cf: Mal kərbaw, Baj krabaw.

29 du:pulu 'gambling' < Mkr, Bug dóbolo? 'gamble' < Dutch dobbelen, Port dobro 'to play-dice, gamble'.

30 du:y? 'money' < MRr doe?, Bug doi? 'money' < Dutch duit; cf: Mal duit.

31 damburu 'drmm' < Mkr, Bug tamboro? 'dmm' < Port tambor; cf: Mal tambur.

32 dawutuwa 'old-man; dmink(ard)' < Mkr, Bug táu 'person' + Mkr, Bug tóa 'old'; cf: Mal oran 'person' + tuha 'old', PHN *ta:uh 'person', PHN *tuqah 'old'.

44 This form is somehow related to $\mathrm{Mkr}$ bugisi ${ }^{2}$ and Bug wugi. It is either a shortening of the $\mathrm{Mkr}$ form (by dropping the final syllable), or a re-analysis of the Bug form based on the presence of $b$ - (rather than $w$-) in $\mathrm{Mkr}$. 
33 dimuru 'northeast (wind)' < Mkr, Bug t lmoro? 'eastwind'; cf: Bug $t$ lmo?, Mal timor < PHN *t 1 :muR 'east(wind)'.

34 du:ka 'steps, Zadder, stairs' < túka? 'steps, Zadder'; cf: Mal tanga 'Id.'.

35 du:mala 'saiz' < Mkr sómbala? 45 'sail'; cf: Mal layar, PHN *la:yaR 'Id.'.

36 dumbilan 'to dive' < $\mathrm{Mkr}$ sumélan 46 'to dive'; cf: Mal solam 'Id.'.

37 dumbulan 'to dive' (alternate of 36, q.v.). 47

38 duwan 'prown' < Mkr, Bug doan 'shrimp, prown'; cf: Mal (h)udan $<\mathrm{PHN}$ *qǔDan 'shrimp, crustacean'.

39 gadaru 'coconut' < Mkr, Bug ka?dáro 'husk, shell (of fruit)'; cf: Mal tampurun 'husk, shard, coconut-shell ladle'.

40 galuku 'coconut' < Mkr, Bug kalúku 'coconut'; cf: Mal kəlapa, ñlor 'Id.'.

41 galuma 'timber' < Mkr galuma? 'deck with loose planks'; Mal golumat 'deck'.

42 galuru 'cigarette, cigarette-paper' < Mkr, Bug kalúru? 'to roll-up; cigar'.

43 gapala? 'Zarge-boat; mudder' < Mkr, Bug káppala? 'boat'; cf: Mal kapal 'Id.'.

44 garay 'Zord, master' < Mkr karáen 'Zord, master, title of person of high rank' [with - loss]; cf: Bug ma-raja, Mal raya 'great, big, high'.

45 garuru 'sail' < Mro, Bug karóro? 'coarse cloth or leaves woven into sail'; cf: Mal karon 'large matwork sack made of coarse material', Ind bagor 'coarse weave of palm leaves'.

46 gataru 'coconut' (alternate of 39, q.v.).

47 gatan 'carpenter's plane' < Mkr, Bug káttan 'Id.'. cf: Mal katam 'Id.'.

45 YM copies the length of the Mkr form, but reduces the - $\mathrm{mb}$ - cluster to a simple - $\mathrm{m}$-. Possibly phonotactics may be the answer; we have noted several occurrences of -u:ma-, but none of -u:mba-.

46 YM has introduced - $\mathrm{mb}$ - for what should be simply -m-, possibly based on the position of stress or accent in Mkr, i.e., "súmelag would have become YM "duimilag, but sumélan had two options, either YM "dumilan or dumbilay (as here).

47 As for footnote 45, but with assimilation or change of $i$ to $u$, which is not uncommon in YM; note Dhatwanu wiña?'yun $=$ wufias'-yun 'disappear', Gumatj wugili $=$ wuguli 'shadow, spirit, image, photo, movie'. 


\section{AUSTRONESIAN LOANWORDS}

$48 \mathrm{gi}: \mathrm{cu}$ 'tobacco' < Mkr késo? 'to scrape or scour (action as involved in the preparation of tobacco for smoking)'.

$49 \mathrm{gu}: \mathrm{Du}$ 'the inside of something (especially a boat)' < Mrr kódo? 'roof or shelter of a boat made of canvass and bamboo'.

50 gulawu 'pearl' < Mkr kúlau 'bezoar-stone; any stony-hard substance (e.g., mother-of-pearl, seeds in fruit, etc.)'.

51 gulikayu 'stringy-bark' < Mkr kúli? 'bark, skin, outercovering' + káyu 'wood, timber'; cf: Mal kulit, Bug úli? 'bark, skin', Mal kayu, Bug aju 'wood, timber'.

52 jaka 'size' < Mkr jákka?, Bug cákka? 'unit of measure from thumb to middle-finger'.

53 jalatan? 'south(wind)' < Mrr, Bug sallátan 'southwind, Zandwind'; cf: Mal selatan < PHN *săla:tan 'south(wind)'.

54 ja:ma 'to work, do' < Mkr, Bug jáma 'do, work; handle, touch'; cf: Mal jamah 'hondle'.

55 jarami 'mimror, glass' < Mkr carámmen [with -n loss]; cf: Mal, Jav cermin, Bug cámmen 'mirror, Zooking-gZass'.

56 jaran 'horse' < Mkr járan 'horse'; cf: Bug aññaran, Jav jaran, Mal kuda 'Id.'.

57 ja:ricari 'cloth, material' < Mkr, Bug cáre-2 'cloth(s), textile', cf: Tag sari-sa:ri 'various things'.

58 jarun 'needle' < Mkr, Bug járun 'needle'; cf: Mal jarum, Jav dom < PHN *Za:Rum 'Id.'.

59 ja:y- (stem in: ja:y-daRpuma, ja:y-gupan) 'to mend, sew' < Mkr, Bug jái? 'to sew'; cf: Mal jahit < PNP *Za:qit 'Id.'.

60 jici 'turtze-shezz' < Mor síssi? 'scale (of fish), shelz (of turtze)'; cf: MaI sisek 'Id.'.

61 jikuyu 'mudarab' < Mrs sikúyu 'crab'; cf: Mal kəpitin, kətam 'crab'.

62 ji:?la 'salt' < Mkr cé?la 'salt(y), brackish'; cf: Bug pa?je, pojje, Mal garam 'salt', asin 'salty' < PHN *qăsin 'salt(y)'.

63 jilicilikan 'revolver' < Mkr sele?-selekan 'pistol'.

64 jinapan 'mifle' < Mkr, Bug sinápan 'mifle, musket' < Dutch snaphaan 'flintzock', Mal sonapan 'gun, musket, rifle'.

65 ji:nara? 'Zight' < Mos sínara? 'clear, bright'; cf: Mal sinar 'ray of light; radiance' < PHN *sinaR 'bright'. 
66 ji:ru 'spoon; shovel' < Mkr si?ru? (or) sírun [with - $]$ loss; cf: 67]; cf: Mal sudu, sandok 'spoon'.

67 jl:run 'spoon' < Mkr sirun 'spoon, Zadze' [cf: 66].

68 ju:lara 'naked' < Mkr sólara? 'naked, bare'.

69 Ju:ra? 'paper; book' < Mkr súra?, Bug súro? 'Zetter'; cf: Mal surat 'Id.'.

70 ju:ru? 'cigar' < Mkr surú? = sarú? 'cigar'; cf: Mal serutu, cerutu, cerut.

71 labina (Gup) 'few, some' < Mrr la?binna 'remainder, sumplus, rest'; cf: Mal labih 'excess, more than'.

72 lacu 'nice, good, smooth' < Mkr láccu? 'smooth; slippery; clever, cute'; cf: Mal Ilcin 'smooth, slippery'. [cf: 77]

73 lambiri 'Zong, tazz' < Mkr (Salayar dialect) lámbere? 'Zong, tazz'; cf: Mr la?bu, Bug lampe?, Mal panjan 'Zong'.

74 lamuru 'cheap (in price)' < Mro lámmoro? 'cheap'; cf: Mal murah 'Id.'.

75 lañin 'bright, clean, polished' < Mar láññin 'totally-clean, pure, beautifuz'.

76 lapara (Gup), Lapara (Gum) 'smooth' < Mrr láppara? 'flat, Zevel, smooth'; cf: Bug lappa, Mal rata 'Id.'.

77 laycu 'nice, good, smooth' (altemate of 72) < Mrer léco? 'to make smooth or slippery'; cf: Mal lecok 'to make smooth and shiny, polish'.

78 Ii:ju, Li:gu 'intoxicated, dmunk' < Mkr If pu 'confused' (cf: Mrr a?- liju-2 'sleep-walking'). [cf: 87]

79 Ii:pa 'material' < Mkr, Bug I ípa? 'sarong'; cf: Mal lipat 'fold(ing)'.

80 lipalipa 'canoe' < Mkr, Bug lépa-2 'dugout canoe (smazlest and simplest type)'.

81 malati 'knife' < Mrr ma?- verb prefix denoting 'to use ( $x$ ), to do $(x)^{\prime}$ (= Mal bor -$)+$ ládin 'knife' [see 150, with Ioss].

82 mangatara 'Makassar(ese)' < Mrr mankásara? 'Id.'; cf: 21.

83 -ma:rata- (stem in: nu:y-ma:rata-miri-yiri) 'diamhoea' < Mkr ma?rasa? 'Id.'; cf: Mal cirit.

84 ma:riyan 'gun, mifle' < Mrr, Bug maríyal 'gun, cannon'; cf: Mal meriam, Jav meriyem 'gun, connon'. 


\section{AUSTRONESIAN LOANWORDS}

85 ma:ta 'pipe' < Mkr, Bug máda? 'prepared-opium'; Mal madat, Arabic madad 'Id.'.

86 miciyan 'boat, vehicle' < biséan 'boat, vessez' (cf: pammisean 'to row').

$87 \mathrm{mi}$ : vu 'dmuk, intoxicated' < Mrr béno 'to stupify, dmug; dmonk' (cf: ammeno 'make dmunk', pammeno 'to intoxicate, drug'); cf: Mal mabuk < PHN *ma-buhuk 'dmunk'.

88 muká (question or agreement particle) 'O.K. ?'< Mkr múkka 'all right, in order, sound, valid', Bug múkka 'useful, appropriate'.

89 na:nici 'alcoholic beverage, strong-dmink' < Mkr, Bug ánisi? 'anisette'; Mal jintan manis 'aniseed' < PHN manis 'sweet'.

90 ra:cun [poisonous-jellyfish] < $\mathrm{Mkr}$, Bug rácun 'poison, venom'; cf: Mal racun 'stomach-poison (in contrast to venom or blood-poison)'.

91 rambani 'equal, together' < Mrr rambanen = rambanan, Bug rambanan 'equal' [with -n loss].

92 ra:pi 'adequate, sufficient, big-enough, smalz-enough' < Mkr rápi? 'to reach, be sufficient'; cf: Bug dapi? 'Id.'.

93 ringi 'costly, expensive' < Mkr, Bug ríngi? 'coin, money'; cf: Mal ringit 'coin, money; dozzar'.

94 ri:ri 'to be nearly boiling (when bubbles start to rise to surface) ( Mkr rére 'to boil, cook'; cf: Mal man-dideh 'to boil'.

95 ru:man 'jungle' < Mkr róman 'woods, forest'; cf: Mal hutan 'Id.'.

96 walu 'day, sun; time; clock' < Mkr állo 'day, sun' [WIth w- addition]; cf: Mal hari 'day', mata-hari 'sun', Bug asso 'day'.

97 wukiri(?) 'to write' < Mkr úkiri? 'to write upon, inscribe'; cf: Mal ukir 'engraving, wood-carving', Bug úki? 'to write'.

98 wun?tin 'banana' < Mkr unt $i$ [with - 0 addition]; Bug utti, Mal punt $i<$ PMP *punti 'banana'.

99 yimbiri 'bucket' < Mkr, Bug embere? 'paiz, bucket' < Dutch emmer 'Id.'; cf: Mal ember 'Id.'. 
GROUP 2: LOANWORDS THAT ARE POSSIBLY MAKASSARESE OR POSSIBLY OTHER AUSTRONESIAN LANGUAGES

100 bacikali 'tin, can' < Mkr bássi, Bug bássi, Mal bəsí 'iron' + Mkr kállin, Mal kalen 'tin, can' [with -n loss].

101 ba:cupacu 'shirt, coat' < Mkr, Bug baju 'jacket', baju-2 'short-sleeved jacket (worn by men)', Mal baju 'shirt, jacket' < Persian bazu 'shoulder'.

102 ba:ju?baju? (alternate of 101, q.v.).

103 balanda 'European, white-man' < Mkr, Bug balánda, Mal balanda 'Holzand, Dutch' < Dutch Holland, Hollander (with unexplained b- for $\mathrm{h}$ - common to Mal/Ind languages).

104 ba:lupalu 'fighting-stick' < Mkrr, Bug pálu-2 'knocker, hammer, club', Mal palu 'to hit with rigid weapon' < PMP *pa:lu? 'beat, hit'.

105 bandira 'flag' < Mkr, Bug, Jav bandéra, Mal bəndera < Port bandeira 'flag, standard, banner'.

106 barambara 'cloth, clothing' < Mkr báran-2 [= báram-báran], Mal, Ind baran-2; Bug wáram-páran 'goods, things, comodities' [with $\rightarrow$ loss].

107 ba:ti 'two-edged knife' < Mrr, Bug bádi?, Mal badek < PHN *badi? 'knife'.

108 bați 'dizlybag, container' < Mkr pátti, Bug pótti, Mal pot 1 'box, chest, case'.

109 ba:țu 'stone' < Mkr, Bug, Mal, Jav bátu 'stone' < PMP *bătu 'Id.'.

110 ba:w? 'fragrant, good-smell' < Mrr, Bug báu? 'fragranes, smel2', Mal buu 'scent, odour' < PMP *ba:hu(?) 'smelz'.

111 bu:cun 'bowl' < Mor busu 'jar, pot' [with $-n$ addition] (or) Mal bocon 'earthenware jar/jug'.

112 bu:lu? 'bamboo' < Mor, Bug búlo, Mal buluh, SPh bu:lu?< PNP *bu: luq [thin-bomboo].

113 bu:na 'perfume, powder, aromatic' < Mkr, Bug búna, Mal buna 'flower, blossom' < PMP *bu: gah 'flower; fruit'. addition). 


\section{AUSTRONESIAN LOANWORDS}

114 bungawa 'boss; govermment' < Mrr, Bug pungáwa 'captain of a ship', Jav pungawa 'official, dignitary', Mal pəongawa 'district-officer' < Skt pumgava 'chief, eminent-person' (Gonda 1973:97).

115 bu:ru 'mingworm' < Mkr, Bug púru' 'pustuze, ulcer, boiz', Mal puru 'sore, uZcer' (specifically due to yaws or Framboesia tropica) < PHN *puRu 'uzcer'.

116 burupuru? (Ritharrnu) 'spots on body due to sunburn or disease' < Mkr, Bug puru-2 'pimples, pustules'. [cf:115]

117 dambaku 'tobacco' < Mkr tambáko, Bug campáko, Mai tambakaw, tembako < Port tabaco 'Id.'.

118 dandurun 'hom' < Mkr, Bug tanru? 'horm', Mal tanduk 'Id.' [with $-\eta$ addition].

119 dapatun 'shoes' < Mkr, Bug sapátu, Mal sepatu < Port sapato 'Id' [with - addition].

120 darima 'to buy' < Mkr, Bug taríma, Mal tarima 'to accept, receive, take'.

121 daripa 'trepang, sea-cucumber' < Mkr', Bug tarípan, Mal taripan 'Id.' [with -口 loss].

122 darungu 'prison' < Mkr, Bug, Ind tarunku < Port tronco 'prison, goal'.

123 darupun 'tezescope' < Mror, Bug tarópon 'telescope', Mal taropon 'tube; telescope; spy-glass'.

124 dingi 'high' < Mkr tíngi, Mal tingi 'high, tall, lofty'.

125 dungara 'year' < Mkr, Bug tungara 'southeast wind', Mal tangara, Min tungara 'Id.'.

126 ga:ci-gaci 'poor, not much money' < kási-ási 'poor, needy', Mal kaseh(an) 'pitiable', kaseh-2 'favour me with'.

127 galiwan 'big-knife, scythe' < Mrr, Bug kaléwan, Mal kəlewan 'sword, sabre'.

128 ga:ran 'coral' < Mrr, Bug káran, Mal, Jav karan 'coral'.

129 garkaci, garakaci, garkaji 'saw (tool)' < Mkr, Bug garagáji, Mal gagaji, gargaji < Skt krakaca- 'carpenter's scav' (Gonda 1973:158)

130 ga:yu 'tree, wood, stick' < Mkr káyu, Mal kayu, Bug aju 'wood, timber; tree (In compounds)' < PMP *ka:yuh 'tree, wood'. 
131 gikina 'tooth' < Mkr, Mal gigi 'tooth', but Mkr gigi-na 'his tooth'.

132 girin-girin 'necklace, ormament, jewellery' < Mkr gírin-2, Mal girln-2, Bug girin-kirin 'ornomental-bells'.

133 gu:la 'syrup, treacle' < Mrr, Bug gólla, Mal gula 'sugar' < Dravidian, Prakrit gula- 'molasses' (Gonda 1973:93).

134 gu:li 'midder' < Mkr, Bug gúlin [w1th - 0 loss].

135 gu:ñjin 'key' < Mkr, Bug kóñci, Mal kunci < Skt kuñci 'Zock, bolt; key' (Gonda 1973:93) [with -n addition].

136 gu:ran 'few, little, not-much, not-many' < Mkr, Bug kúran, Mal, Jav kuran 'too-little, falling-short, not-quite'.

137 ja:bu, ja:pu 'soap' < Mkror, Bug sábun, Mal sabun < Arable sabun 'soop' [with - 1 loss].

$138 \mathrm{ja}$ :ga, ja:ka 'to look-after, care-for' < Mkr, Bug jága 'watch, look-out', Mal jaga 'be-cowake, vigilant' < Hindi jāgā 'wakeful' (Gonda 1973:94).

139 jalwara 'trousers' < Mkr salúwara?, Bug saluwára?, Mal saluar < Persian shalwar (or) Arable sarwal 'Id.'.

140 jambaka 'steel, roofing iron' (Gum), 'tin, pannikin' (Gup) < Mrar, Bug tambága, Mal tembaga 'copper' < Prakrrit tamba-ga 'copper' (Gonda 1973:91).

141 jamban 'tomarind' < Mkr cámba, Bug cámpa Tamarindus Indica L. [with $-\eta$ adaltion].

142 jambaya 'prayer' < Mkr sambáyan 'Muslim worship', Mal sembahyan 'divine worship' (< səmbah 'obeisance' + yan 'gods, divinity') [with -n loss]; ${ }^{49}$ Bug sampájan 'Id.'.

143 jambi 'change, exchange' < Mkr sámbe 'money-changer', Tban sambi? 'get in exchange', SPh sámbi? 'to change, replace' $<$ PHN *sambi? 'change, barter'.

144 jandu 'pipe' < Mkr, Bug cándu, Mal, Jav candu 'prepared-opium (softened with water before use)'.

145 japatun 'shoes' (alternate of 119, q.v.) [also with - ] addition]. 
146 jinjin 'wire; earmings'. Mkr ciñcin, SPh sinsin; Mal cincin, Bug ciccin< PHN * cincin 'ming'. 50

147 ju:lin 'mouth-organ' < Mkr, Bug súlin, Mal sulin 'fife, flute, flageolet'.

148 ju:ngu 'hat' < Mkr, Bug sónko? 'hat', Mal sonkok 'fez-like cap'.

149 landira 'Zamp' < Mrr, Bug lantéra, Mal lantera < Port lanterna 'Zantern'.

150 la:ti 'knife' < Mkr ládin 'knife', Mal ladin 'cleaver' [with - $n$ loss]; alternate Lati; see also malat $i$ (81).

151 la:tun 'sinker; lead; fillings in teeth' < Mkr, Bug ládun, Mal batu- ladon 'sinker, plummet'.

152 miña 'paint, tax' < Mkr, Bug miñña?, Mal miñak 'oil, fat'.

153 mutiyara? 'pearl; shell' < Mkr, Bug mutiára, Mal mutiara, mutia 'pearl' < Prakrit muttia 'pearl' (Gonda 1973:93).

154 nu:na 'white-woman' < Mkr, Bug nóna 'Miss, Mrs', Mal nona 'miss, unmarried European or Chinese girl'.

155 ra: ndin 'chain' < Mrr. Bug ránte 'chain', Mal rantay 'chain; necklace; links' [with -I addition].

156 rupiya 'money' < Mkrr, Bug rupia, Mal rupiah 'money' < Skt rūpya- 'silver; rupee'.

157 ru:ti i 'bread' < Mrre, Bug róti, Mal roti 'Id.' < Indic roTi 'bread without yeast' (Gonda 1973:94).

158 wa:ni 'wind, air' < Mar, Bug anin, Mal anin < PMP *ha: jin 'wind, air' [with w- addition and -1 loss].

\section{GROUP 3: LOANWORDS THAT ARE PROBABLY NOT MAKASSARESE}

159 baramata 'eyeglasses'. Note Mkr paramáta, Mal parmata 'jewel, precious stone' (<Skt); several SPh languages (e.g., Bisayan) have forms like pára 'for' + matá 'eyes' which offer a closer semantic match, but the source language cannot be specified.

160 ba:ran 'cane-knife, machete' < Mal paran 'cleaver, machete'; cf: Mkr béran 'chopping-knife, cleaver', which would have been borrowed as YM *bi:ran.

50 Although YM appears to copy the SPh form more precisely, it is quite possible that YM speakers interpreted the form as a reduplication of a single syllable, as indeed it was in PHN and is amongst $\mathrm{SPh}$ languages. 


\section{ABORIGINAL HISTORY 1981 5:2}

161 barawu (Ritharmu) 'boat' < Mal porahu 'Id.'; cf: Mkr sámpan káppala? 'Id,'.

162 ba:wan 'potatoes, vegetables'. Mal bawan 'bulb of Allium sp' < PAN *ba:wan 'garlic'; cf: Mkr báwan 'no-good, worthless'.

163 bulpul 'feather' flower'. Cf: PMP *bulbúl 'hair; feather', SPh bulbúl 'body-hair, feathers, fur'; not MKr búlu 'bodyhair'; Mro does not allow consonant clusters other than NC (nasaltconsonant), and words can only end in the consonants $-?$ or $-\eta$.

164 buL?buL?-yu- (Ritharmu) 'to sneak along with branches as camouflage'. [See 163, related to PMP *bulbul (?).]

165 Dakul 'axe'. Cf: SPh pa-dăkúl 'axe, hatchet'; not Mkr pankúlu?, PHN *wa:say (Bug uwase), nor PIN *kapak (Mal, Ind, Baj kapak); cf: Ind cankul 'broad hoe'.

166 di:tun (Gumatj) [dog's name]. Cf: PHN *ti:tun 'dog, puppy'; not Mrr konkon nor Bug ásu 'dog'. [Compare with di:tun] 'buffalo' (28) in other YM dialects.]

167 dapa 'heel'. Cf: PHN *dăpáh 'heel', SPh dapá(h) or dapá-2 'Id.'; not Mkr kátulu? 'heel', Mal tumit 'heel', Mkr, Mal káki 'foot'.

168 dudi 'bottom, behind, buttocks'. Cf: PMP *uDahi 'behind' + *di- locative > Iban dudi 'Zate; behind' Jav udi 'posterior; behind'; not Mkr bóko 'behind, back-of' or Mkr dónko? 'back'.

169 dumbul? 'short'. Cf: Mal tumpul 'blunt, dull'; not Mkr típulu? 'blunt, duzz' or $\mathrm{Mkr}$ bódo 'short'.

170 gaDa-gaDa 'separate, apart'. Cf: SPh káda káda-2 < Spanish cada 'each'.

171 ga:rup (Gumatj) 'sack', (Gupapuynu) 'blanket; bag' < Mal karon 'Zarge matwork sack of coarse material'; contrast \#45.

172 gayit 'shovel-nosed spear'. Cf: Mal kait, Mrr kai? 'hook'.

173 jaLajaLa?-yu- (RItharmu) 'to stagger, walk-unsteadily'. Cf: PAN *Za:laN 'road; to walk, wander', Mal jalan 'road; to walk'; not Mkr lálan 'walk'.

174 jalatan 'south'. Cf: Mal solatan 'south(wind)' and YM jalatan? (53). 51

51 A number of speakers have this as a variant; note both alveolar $t$ and $n$, which rule out Mkr as a source. 
175 jalinda 'sail, cloth, towel, sheet'. Cf: Mal solendan 'scarf, sling, cloth-band', Mrr salinrin 'Id.' [with $-\eta$ loss].

176 jaL?jaL?-yun 'to masturbate'. Cf: SPh sarsar (or) salsal 'to work-metal; to masturbate'. 52

177 jaru? 'sour, poison(ous)'. Cf: Mal jərók 'acid-fruit, citric-fmit'. 53

178 ma:jin (Gumatj) 'bitter, sour'. Cf: Mal masin 'brackish, salty' < PAN *ma-qăsin; not Mkr cé?la 'salt(y)', Mkr kácci 'sour'.

179 ya: (Gupapuynu) 'ah, oh yes'. Cf: Mal ya 'yes, it is so'< Dutch ya 'Id.'.

\section{GROUP 4: POSSIBLE AUSTRONESIAN LOANWORDS (REQUIRING FURTHER} RESEARCH)

180 ba:cu 'digging-stick'. Cf: Mal bacok 'to hack, slice-off', Jav pacul 'hoe', Mkr paso? (= Mal pasak) 'peg, wedge'.

181 ba:kala 'harpoon'. Source language not identifiable.

182 bakura 'robber'. Cf: YM baluka (05); source language not identifiable.

183 baNara 'clear of mubish'. Cf: Mkr pánnara? 'to let stay uncleared or messy'; possibly a case of misunderstanding, or of semantic reversal.

184 ba:pa? 'father, uncle (FB)'. Cf: Mro, Mal, Jav bápa? < PHN *bapa?; note the stress Irduced vowel length. 54

185 barupu 'tobacco'. Source language not identifiable.

186 batuman 'swimming-goggles'. Cf: Mkr padoman, Mal podoman 'compass', if the product of misunderstanding or extension of meaning.

187 bicara 'like-this' (note inflection: blca-na 'it was like this'). Cf: Mal bicara 'speak', Mkr bicara 'speak; thing, affair, matter; given that'.

52 See footnote 27.

$53 \mathrm{Mal}-\mathrm{k}$ is pronounced [ $P$ ], and [a] is likely to be interpreted as [a].

54 Warner (1932:491), among others, argues against this as a chance agreement, citing Australian "pa:pa or "pa:pi as the source. YM speakers recognise maLu and gunu 'father' as indigenous terms, and refer to many Makassan captains as 'ba:pa-X'; furthermore, the cognate of the Australian forms appears to be $Y M$ wa:wa 'brother', with regular change of *-p>-w-. 
188 binal 'axe'. Source language not identifiable. Macknight says 'this is a good case of a specifically Macassarese derivation' relating it to Mkr pánkulu? 'axe', 55 which YM speakers would have borrowed as either *bankulu or *ba:nkulu. It is not related to any of the forms cited at \#165.

189 bu:cama (Gupapuynu) 'to buizd'. Cf: YM ja:ma (54): note the prefix bu- in Bajau (< PHN *bəR- as in Mal bər-), e.g., bu-gulin 'to rolz', bu-guno 'to be useful'.

190 buluk 'white-feathers (used for armbond)'. Source language not identifiable, but see discussion at 163 .

191 bu:Luku 'rotten, mouldy'. Cf: Ind bulukan 'mouldy, mildewed', SPh bulúk 'rotten, decayed'.

192 bulumbul 'white-hair'. Cf: Mkr búlu 'down, fluff' and 163.

193 bu:tiri 'to deceive, tell a lie'. Cf: PHN *butiR 'lie, falsehood' > Bisayan butíg 'Id.'; an Ind cognate could show a Mkr-like development of ${ }^{*} R>r$, followed by a support vowel (amongst other languages of Celebes).

194 Daci 'very itchy skin disease (used to be fatal)', considered to have been introduced by Makassans, but source language not identifiable.

195 Dalwa-Dalwa 'thick material (like canvass)'. Source language not identifiable.

196 Da:mbak 'boat'. Cf: Mal dempak 'squat, broad, Zow in proportion to its breadth' (could have been used to describe some kinds of boats).

197 dandana 'tin'. Cf: Mal, Jav dandan 'Zarge copper vessel for steaming rice' (possibly an indirect loan through a vowelintroducing language such as Anindilyakwa); Mkr dandanan 'bar, ingot' [with $\rightarrow$ loss].

198 Danja 'inside; hold of a ship'. Source language not identifiable.

199 damam? 'dinghy'. Cf: Mal sampan, Mkr sampan 'canoe, dinghy'.

200 dambala 'small inlet where conoe stands; landing'. Cf: Mal jambatan 'Zanding, gangway'. 


\section{AUSTRONESIAN LOANWORDS}

201 damuku (Gupapuypu) 'canoe'. Source language not identifiable. 202 daramaka [dog-name]. Cf: Mkr taran-mata 'sharp-eye'.

203 du:In (Gupapuypu) 'Zadder'. Cf: Baj odon 'Id.' and 34.

204 gacipali [bad sickness: boils with more than one head, sometimes fatal]. Source language not identifiable, but cf: Mal kasih 'give' + pali 'taboo'.

205 gadara (Gupapuypu) 'coral'. Cf: Mor katáran 'form, shape' (or) Mror gattara? 'tinsel; shining substance'.

206 gadubala, gaduwala 'paddze, oar'. Source language not identifiable.

207 garamat 'sky, above'. Cf: Mal karamat 'saintly, working miracles'; may be product of misunderstanding, or simply a chance resemblance.

208 gatabana 'buffalo, caraboa'. Cf: Mal kərbaw, Baj krabaw 'Id.'.

209 gayi-gayi (Gupapuypu) 'core of boiz'. Cf: Mre gae 'open-up'. 210 giri? 'things, gear, pieces, clothes'. Cf: Mkr kére 'why?, what-for?'; possibly a product of misunderstanding.

211 gitkit-tun 'to Zaugh.' Cf: Tondano ke?ke? 'Id.'.

212 gucikan 'pocket'. Source language not identifiable.

$213 \mathrm{gu}:$ Iku 'tobacco; ash; buts'. Source language not identifiable.

214 gulun 'medicine; doctor'. Cf: Mal gulon, Mkr gulun 'to roll-up'; this action is involved in rolling up medicinal leaves and poultices.

215 gu:ta (Gupapuypu) 'pliable iron, tin'. Source language not identifiable.

216 jakaRun 'cup, pannikin'. Cf: Bug, Mar cánkiri?, Mal, Jav cankir 'cup'.

217 jalamat 'foot'. Cf: Mal solamat-jalan 'good-trip', said when people go away; possibly the product of misunderstanding.

218 jalatun 'sinker'. Cf: 151, possibly with sa- or sa- 'one' as prefix.

219 jaturu (Gumatj) 'sour, poison(ous)'. Source language not identifiable.

220 jimbiya (Gupapuynu) 'axe'. Source language not identifiable. 
221 jimuku 'piece of steel, iron-crowbar'. Source language not identifiable.

222 jirit 'small stick across sail from mast'. Source language not identifiable.

223 Lucu (Gumatj) 'big-red-kangaroo'. Cf: Mal Iucu 'cute, amusing; make fun of'.

224 lulu 'coconut'. Source language not identiflable.

225 Lu:Lu (Gupapuygu) 'fence, fenced-in area'. Cf: MRr lúlu 'contents'.

226 lu:ndun (Gupapuynu) 'black-tobacco' (archaic). Source language not identifiable.

227 Luniñ 'pipe'. Source language not identifiable.

228 Luplup-tun 'to bathe; swim'. Cf: Tondano li?lip 'swim'.

229 marwala 'paddle, oar'. Source language not identifiable.

230 matin? 'paddle, oar'. Cf: Mal masin 'machine'.

231 mi:wun (Gumatj) 'buffalo, big-animal'. Source language not identifiable.

232 miyapunu 'turtze'. Cf: PMP *poñuh, SPh punu 'tortoise', although the miya-part is not identifiable; ${ }^{56}$ this may be the product of chance resemblance.

233 muNungari (Gumatj) 'glass-bottle; piece of glass'. Source language not identifiable.

234 mu:wayak (Gumatj) 'calico, material; clothes'. Source language not identifiable.

235 Nupuyna 'coconut'. Source language not identifiable.

236 nama? 'mother'. Cf: Mkr ámma? 'mother' [with' $\mathrm{n}$ - since YM does not allow a word to begin with a vowel (see 89)]; contrast PAN *ama(?), Bug ama 'father'. 57

237 Raki? 'rope, stming'. Cf: Mkr ráki?, Mal rakit 'raft (Zogs or bamboo tied together)'

56 However, note m- : L- alternation in forms like mi:gu : Li:gu (87:78), Gumatj miyaman : Gupapuy gu Liyaman 'sing', possibly miya- is an alternate of YM Liya 'head', i.e., turtle (shell) + head = 'living tortoise'.

57 There is, of course, a perfect Australian cognate of 'yama-, e.g., Koko-Bera gamá-y ər 'mother', Warlpiri nama 'female', ngamaDi 'mother'. YM speakers generally recognise gaNDi as their word for 'mother', which would be cognate with the Warlpiri form (above), i.e., "gamaDi $>$ "nam()Di $>$ gaNDi (with assimilation of $\mathrm{m}$ to retroflex $\mathrm{D})$. The agreement with $\mathrm{Mkr}$ is certainly striking, especially in light of the fact that the Mkr form disagrees with the other AN evidence, viz: PAN 'amal ') 'father', 'ina( ') 'mother'. 


\section{AUSTRONESIAN LOANWORDS}

238 rica-rica (Gumatj) 'to dive (for trepang)'. Cf: Mkr réja-2 'to do together, to do in a large group'.

239 waDak, waDaka (Gumatj) 'seat of canoe or dinghy'. Source language not identifiable.

240 wa:k 'crow'. Cf: PHN *ǔak 'crow'; onomatopoeia is probably involved.

241 walpaNa 'canoe'. Source language not identifiable.

242 waTu 'dog'. Note resemblance to PAN *u-a:su 'dog', which in some languages has reflexes watu, although Bug ásu.

243 wa:wula (Gupapuynu) 'axe'. Source language not identifiable.

244 wiri-cun 'to go paddling or rowing'. Source language not identifiable.

245 wulu (Gupapuynu) 'hair of dead person of Dhinas moiety'. Cf: Mkr, Bug ulu, Mal (h)ulu 'head; chief'; contrast Mkr', Mal bulu, Bug, Jav wulu 'hair, plumage, bristles' ('bodyhair, not head-hair').

246 wuramu 'Makassan grave-post'. Cf: Mal oran 'person' + -mu 'your'. Arnhem Landers claim the word and the design to be of Makassan origin, but no Mkr word can be found. Cense discusses this problem. 58

247 wurapanda 'white-person'. Possibly Mal: oran 'person' + bolanda 'Dutch'; it is unlikely to be a reduction of ujur pandan 'Makassarese city and port', since it refers only to 'white-person' and never to Makassans, Japanese, Chinese, etc. Compare: Anindilyakwa (Groote Eylandt) urabaranda, urubalanda, urubanda 'white-person'.

248 yiki 'knife; anything sharp made of steel'. Source language not identifiable.

249 yu: 'yes'. Cf: Mrr io 'yes'. Words like ya- and yu-are distributed amongst many Australian languages and are likely to be descended from Proto Pama-Nyungan rather than loans.

58 Cense 1952 (although neither he nor Wirjosuparto 1969:157 associate the YM form with any Mkr or AN word) states that "wuramu is said to mean something like "swindler, thief, or collector of moneys" , (translation by C.C. Macknight, personal communication). 
It is the long vowel that makes this particular form suspect

as a $\mathrm{Mkr}$ loan, although, conversely, the $\mathrm{Mkr}$ form may be a borrowing from Aboriginal languages since AN languages generally have cognates of PHN *ha?a or PHN *ai? 'yes'. The factor of chance resemblance must also be considered.

NORTHERN TERRITORY DEPARTMENT OF EDUCATION AND

\section{SCHOOL OF AUSTRALIAN LINGUISTICS, DARWIN COMMUNITY COLLEGE}

\section{BIBLIOGRAPHY}

Berndt, Ronald M. and Catherine H. Berndt. Amhem Land its history and its people Melbourne, 1954.

Cense, A.A 'Makassaars-Boeginese prauwvaart op Noord-Australië', Bijdragen tot de taat, land- en volkenkunde, 108, 1952:248-264.

- Makassaars-Nederlands Woordenboek 'S-Gravenhage, 1979.

Earl, George W. 'Notes on northern Australia and the neighbouring seas', Journal of the Royal Geographical Society, 12, 1842:139-141.

- The native races of the Indian archipelago. Papuans. London, 1853.

Fox, James J. 'Notes on the southern voyages and settlements of the Sama-Bajau', Bijdragen tot de taal, land- en volkenkunde, 133, 1977:459-465.

Gonda, J. Sanskrit in Indonesia New Delhi, 1973.

Jennison, J.C. 'Notes on the language of the Elcho Island Aborigines', Transactions of the Royal Society of South Australia, 51, 1927:177-192.

Lowe, Beulah. Temporary Gupapuynu dictionary, ed Michael Christie. Milingimbi, 1976.

Macknight, C.C. 'Macassans and Aborigines', Oceaniz, 42(4), 1972:283-321.

- The voyage to Marege': Macassan trepangers in northern Australia Melbourne, 1976.

Matthes, B.F. Makassaarsch-Hollandsch Woordenboek mel Hollandsch-Makassaarsche woordenlijst. . Amsterdam, 1859; 2nd edition, The Hague, 1885.

Mountford, Charles P. Art myth and symbolism. Records of the American-Australian Scientific Expedition to Amhem Land 1. Melbourne, 1956.

Ngewa, Djirong Dg. Fonemik Bahasa Makassar. Ujungpandang, 1972.

Nothofer, Bernd. A comparative study of Buginese and Macassarese. Unpublished MS, Yale University, 1970.

Said, M. Ide, DM. Kamus Bahasa Bugis-Indonesia Jakarta, 1977.

Schebeck Bernard. Dialect and Social groupings in north east Arnhem Land. Unpublished MS, A.I.A.S. Library, Canberra, n.d.

Schneeberger, W.F. 'A short vocabulary of the Banggi and Bajau language', Journal of the Malayan Branch of the Royal Asiatic Society, 15(3), 1937:145-164.

Turner, D.H. Tradition and transformation: a study of the Groote Eylandt area Aborigines of northern Australia Canberra, 1974.

Urry, James and Michael Walsh, 'The lost "Macassar language" of northern Australia', Aboriginal History, $5(2)$, 1981:91-108.

Warner, W.L. 'Malay influence on Aboriginal cultures of north-eastern Arnhem Land', Oceania, 2(4), 1932:476-495.

Wirjosuparto, Sutjipto. 'Pengaruh Bahasa dan Kebudajaan Makasar di Australia Utara', Manusia Indonesia, 3, 1969:140-159.

Warren, James F. 'Slave markets and exchange in the Malay world: the Sulu Sultanate, 1770-1878', Journal of Southeast Asian Studies, 8(2), 1977:162-175.

Wolff, John U. 'Malay borrowings in Tagalog', in Cowan, C.D. and O.W. Woltors eds Southeast Asian history and histeriography: essays presented to D.G.E. Hall Ithaca, 1976:345-367.

Worsley, Peter M. 'Early Asian contacts with Australia', Past and Presenh, 7, 1955:1-11.

Zorc, R. David Paul. 'Functor analysis: a method of quantifiying function words for comparing and classifying languages', in Wölk, Wolfgang and Paul L. Garvin eds Fifth LACUS forum Columbia, South Carolina, 1978:510-521.

- Functor analysis of Yolngu Bachelor, 1979. 